\title{
PASAR MODAL SYARIAH DAN KONVENSIONAL
}

\author{
Fadilla \\ Prodi Perbankan Syariah STEBIS IGM Palembang \\ Email :dilla@stebisigm.ac.id
}

\begin{abstract}
ABSTRAK
Investasi adalah sesuatu yang harus dilakukan hari ini. Investasi sendiri pada dasarnya adalah pengumpulan uang atau apa yang dapat dibandingkan dengan apa yang merupakan simpaun yang akan digunakan untuk masa depan. Hari ini kebanyakan orang berinvestasi dalam saham. Saham adalah surat berharga yang dijual di pasar modal. Pasar modal terbagi menjadi 2 (dua) jenis yaitu pasar modal konvensional dan pasar modal syariah.

Dari hasil penelitian ini dapat disimpulkan bahwa pasar modal syariah yang diperdagangkan sekuritas harus dari perusahaan yang dalam menjalankan kegiatan operasionalnya tidak bertentangan dengan prinsip syariah. Padahal di pasar modal biasa tidak ada aturan yang mengatur kegiatan operasional perusahaan. Dasar hukum pasar modal syariah pada dasarnya adalah Al-Qur'an dan Hadis yang ditegaskan oleh Nasinonal Syariah Council Fatwa (DSN) sementara pasar modal konvensional adalah UU Pasar Modal, yaitu UU No.8 tahun 1995. Dalam pelaksanaan modal kegiatan pasar syariah diawasi oleh DSN (National Sharia Board), sementara pasar modal konvensional tidak. Indeks harga saham konvensional termasuk IHSG, LQ45, Kompas 100 dll, dan indeks harga saham Syariah adalah JII (Jakarta Islamic Index) dan DES (Daftar Efek Syariah)
\end{abstract}

Kata Kunci; Pasar, Modal, Syariah, Konvensional

\section{DASAR PEMIKIRAN}

Investasi merupakan sesuatu yang harus dilakukan dizaman sekarang ini. Investasi sendiri pada hakikatnya pengumpulan uang atau yang dapat dipersamakan dengan itu yang di simpaun untuk kemudian digunakan untukmasa yang akan datang. Investasi pada hakikatnya terbagi menjadi beberapa macam yaitu investasi jangka pendek dan jangka panjang. Kebanyakan investasi yang dilakukan masyarakat dalam bentuk investasi jangka pendek dengan menabungkan uangnya ke Bank dalam bentuk deposito. Pada dewasa ini kebanyakan masyarakat menginvestasikan dalam bentuk saham. Saham merupakan surat berharga yang dijual dalam pasar modal. Pasar modal terbagi menjadi 2 (dua) macam yaitu pasar modal konvensional dan pasar modal syariah.

Pasar modal (capital market) merupakan pasar untuk berbagai instrumen keuangan jangka panjangyang bisa diperjualbelikan, baik dalam bentuk utang maupun modal sendiri. Adapun pasar modal syariah merupakan Pasar modal syariah merupakan 
pasar modal yang merupakan prinsip syariah dalamkegiatantransaksinya dan terbatas dari-hal-hal yang dilarang, seperti riba, perjudian, spekulasi dan lain sebagainya. Penelitian ini akan membahas tentang perbedaan pasar modal konvensional dan syariah secara lebih mendalam.

\section{PEMAHAMAN}

\section{A. Konsep Dasar Pasar Modal}

\section{Pengertian Pasar Modal}

Pasar modal (capital market) merupakan pasar untuk berbagai instrumen keuangan jangka panjangyang bisa diperjualbelikan, baik dalam bentuk utang maupun modal sendiri.

2. Instrumen dalam pasar modal

1. Saham

2. Obligsi

3. Waran

4. Right

5. Obligasi konvertibel

6. Produk turunan (put atau call option) (Sudarsono, $2010: 191$ )

3. Sejarah Pasar Modal

Aktivitas pasar modal dimulai sejak tahun 1912 di Jakarta. Efek yang diperdagangkan adalah saham dan obligasi perusahaan milik Belanda serta obligasi milik pemerinta Belanda. Aktivitas ini berenti pada peran dunia kedua. Memasuki era kemerdekaan bursa efek diaktifkan kembali dengan diterbitkan obligasi pemerintah RI tahun 1950. Pengaktivan ini didukung dengan UU darurat tentang Bursa No. 13 taun 1951 yann kemudian ditetapkan denan UU No.15 taun 1952 (Sudarsono, $2010: 192$ ).

Untuk meningkatkan aktivitas pasar modal pemerintah membentuk membentuk Badan pelaksana Pasar Modal (BAPEPAM) yang untuk kemudian menjadi Badan Pengawas Pasar Modal. Untuk merangsang perusahaan melakukan emisi pemerintah memberikan keringanan atas pajak perseroan sebesar 10-20\% selama 5 tahun sejak perusahaan yang bersangkutan go public. 
4. Struktur Pasar Modal Indonesia

Untuk mendukung kegiatan pasar modal diperlukan lembaga yang dapat membantu menunjang kegiatan pasar modalagar dapat berjalan dengan baik. Adapun Lembaga penunjang tersebut antara lain:

a. BAPEPAM

Sesuai dengan keputusan Mentri Keuangan Republik Indonesia No. 53/KMK.01/1997, Badan Pengawas Pasar Modal (BAPEPAM) Melaksanakan tugas di bidang pembinaan, pengaturan, dan pengawasan kegiatan padar modal yang berada di bawah pertanggungjawaban langsung kepada Mentri Keuangan dan dipimpin oleh seoran ketua.

b. Bursa Efek

Bursa efek adalah lembaga/perusahaan yang menyelenggarakan/menyediakan fasilitas sistem pasar untuk mempertemukan penawaran jual dan beli efek antara berbagai perusahaan/perorangan yang terlibat dalam tujuan memperdagangkan efekefek perusahaan-perusahaan yang telah tercatat di bursa efek.

c. Lembaga Kliring dan Penjamin

Lembaga kliring dan penjamin adalah lembaga pendukung terselenggaranya sistem pasar modal secara lengkap, selain lembaga penyimpanan dan penyelesaian. Lembaga ini menyediakan jasa kliring dan penjaminan penyelesaian transaksi Bursa.

d. Lembaga Penyimpanan dan Penyelesaian

Lembaga/perusahaan yang menyelenggaraan kegiatan kustodian sentral (tempat penyimpanan terpusat) bagi Bank Kostudian, perusahaan efek dan pihak lain. Saat ini diselenggarakan oleh PT Kustodian Sentral Effek Indonesia.

e. Perusahaan Efek

Perusahaan yang melakukan kegiatan usaha sebagi penjamin emisi efek , Perantara Pedagang efek atau Manajer Investasi (UU Pasar Modal). Perusahaan efek dapat menjalankan usaha tersebut setelah mendapat izin dari Bapepam.

1) Penjamin emisi adalah perusahaan sekuritas yang membuat kontrak dengan emiten untuk melakukan penawaran umum bagi kepentingan emiten tersebut.

2) Perantara pedagang efek (Broker) 
3) Manajer Investasi. Perusahaan perorangan yang telah mendapat izin usaha dari Bapepam untuk mengelolah portofolio efek untuk para investor/nasabah baik secara perorangan atau kolektif.

f. Lembaga Penunjang

1) Bank Kustodian. Bank Kustodian berfungsi memberikan jasa penitipan efek dan harta lainnya yang berkaitan dengan efek serta jasa lainnya.

2) Biro Administrasi Efek (BAE), Lambaga penunjang pasar modal yang berperan dalam administrasi efek, baik pada saat pasar perdana maupun pada pasar sekunder.

3) Wali amanat, Merupakan pihak yang dipercaya untukmewakili kepentingan seluruh pemegang obligasi atau sekuritas utang.

4) Penasehat investasi.Perusahaan yang memberikan nesihat kepada pihak lain mengenai penjualan atau pembelian efek dengan memperoleh imbalan jasa. Untuk perorangan disebut dengan wakil manajer investasi.

5) Pemeringkat efek, Perusahan swasta yang melakukan peringkat/rangking atas efek yang bersifat utan (seperti obligasi).Tujuan pemeringkatan adalah untuk memberikan pendapat mengenairesiko suatu efek utang.

g. Profesi Penunjuang

1) Akuntan

2) Konsultan hukum

3) Penilai

4) Notaris

h. Emiten

Istilah emiten mengacu kepada kegiatan yang dilakukan perusahaan yang menjual sahamnya kepada investor melalui penawaran umum.

i. Perusahaan Publik

Perseroan yang sahamnya telah dimiliki sekurang-kurangnya 300 pemegang saham dan memiliki modal disetor sekurang-kurangnya Rp. 300 Miliyar.

j. Reksadana merupakan salah satu alternatif investasi bagi masyarakat pemodal, kususnya pemodal kecil dan pemodal yan tidak memiliki banyak waktu dak keahlian untuk menghitung resiko atas investasi mereka. 


\section{Penawaran Umum}

Penawaran umum atau go publik adalah kegiatan penawaran saham atau efek lainnya yang dilakukan oleh emiten (perusahaan yang akan go publik). Penawaran umum meliputi kegiatan-kegiatan sebagai berikut :

1) Periode pasar perdana adalah ketika efek ditawarkan kepada pemodal oleh pnejamin emisi melalui para agen penjual yang ditunjuk.

2) Penjatahan saham yaitu pengalokasiaan efek pesanan para pemodal sesuai dengan jumlah efek yang tersedia

3) Pencatatan efek dibursa

Adapun tahapan-tahapan dalam penawaran umumadalah :

1) Sebelum emisi, persiapan yang dilakukan dalam memenuhi persyaratan penawaran umum.

2) Tahapan emisi, yaitu masa dilakukan penawaran umum hingga saham-saham yang telah ditawarkan dicatat dalam Bursa Efek

3) Tahapan sesudah emisi, yaitu berupa taapan pelaporan sebaaikonsekuensi atas penawaran umum tersebut.

Indeks harga Saham :

a. IHSG (Indeks Harga Saham Gabungan )

b. LQ45

c. Kompas 100

d. Indeks Bisnis 2007

e. Indeks SRI-KEHATI,

f. Dan lain-lain, (http://blog.valbury.co.id/article/read/Jenis-Jenis-Indeks-SahamBEI-Yang-Perlu-Diketahui, diakses tanggal 16 Oktober 2018)

\section{B. Pasar Modal Syariah Konsep Investasi Islam dan Pasar Modal Syariah}

Investasi merupakan salah satu ajaran dan konsep yang memenuhi proses tadrij dan trichotomy pengetahuan tersebut (Huda dan Muamad, 2013 : 185). Hal tersebut dijelaskan dalam Al-Quran surat al-Hasyr ayat 18 sebagai berikut : "Hai orang-orang yang beriman, bertawalah kepada Allah dan hendaklah setiap diri memperhatikan apa yang telah diperbuatnya untuk heri esok(akhirat) dan bertakwalah kepada Allah, sesungguhnya Allah mengethui apa yang kamu kerjakan “ 
Pasar modal syariah merupakan pasar modal yang merupakan prinsip syariah dalamkegiatantransaksinya dan terbatas dari-hal-hal yang dilarang, seperti riba, perjudian, spekulasi dan lain sebagainya. (Nurhayati dan Wasilah, 2015 : 348).

\section{Jenis Efek Syariah}

Ada 5(lima) jenis efek syariah yang dapat diperdagangkan dalam Pasar Modal Syariah yaitu:

1) Saham Syariah adalah bukti kepemilikan atas suatu perusahaan yang memenuhi kriteria berdasarkan fatwa DSN-MUI, dan tidak termasuk saham yang memiliki hak-hak istimewa.

2) Obligasi syariah adalah surat berharga jangka panjang berdasarkan prinsip syariah yang dikeluarkan emiten kepada pemegang obligasi syariah yang mewajibkan emiten untuk membayarpendapatan kepadapemegang obligasi syariah.

3) Unit Penyertaan Kontrak Investasi Kolektif (KIK) Reksa Dana Syariah Adalah suatuukuran yang menunjukkan bagian kepentingan setiap pihak dalam portofolio investasi suatu KIK Reksa Dana sSyariah.

4) Efek Beragun Aset (KIK EBA) syaria adalah efek yang diterbitkan ole kontrak investasi kolektif EBA Syariah yang portofolionya terdiri atas aset keuangan berupa tagihan yang timbul dari surat berharga komersial

5) Surat Berharga Komersial Syariah adalah surat pengakuan atas suatu pembiayaan dalam jangka waktu tertentu yang sesuai dengan prinsip-prinsip syariah.

6) Surat berharga syariah lainnya.(Nurhayati dan Wasilah, $2015: 353$ ).

Adapun Efek syari'ah dalam fatwa DSN MUI No. 40/DSN-MUI/X/2003 tentang Pasar Modal dan Pedoman Umum Penerapan Prinsip Syari'ah di Pasar Modal adalah :

a. Efek Syariah mencakup Saham Syariah, Obligasi Syariah, Reksa Dana Syariah, Kontrak Investasi Kolektif Efek Beragun Aset (KIK EBA) Syariah, dan surat berharga lainnya yang sesuai dengan Prinsip-prinsip Syariah.

b. Saham Syariah adalah bukti kepemilikan atas suatu perusahaan yang memenuhi kriteria prinsip syari'ah, dan tidak termasuk saham yang memiliki hak-hak istimewa. 
c. Obligasi Syariah adalah surat berharga jangka panjang berdasarkan Prinsip Syariah yang dikeluarkan Emiten kepada pemegang Obligasi Syariah yang mewajibkan Emiten untuk membayar pendapatan kepada pemegang Obligasi Syariah berupa bagi hasil/margin/fee serta membayar kembali dana obligasi pada saat jatuh tempo.

d. Reksa Dana Syariah adalah Reksa Dana yang beroperasi menurut ketentuan dan prinsip Syariah Islam, baik dalam bentuk akad antara pemodal sebagai pemilik harta (shahib al-mal/rabb al-mal) dengan Manajer Investasi, begitu pula pengelolaan dana investasi sebagai wakil shahib al-mal, maupun antara Manajer Investasi sebagai wakil shahib al-mal dengan pengguna investasi.

e. Efek Beragun Aset Syariah adalah Efek yang diterbitkan oleh kontrak investasi kolektif EBA Syariah yang portofolio-nya terdiri dari aset keuangan berupa tagihan yang timbul dari surat berharga komersial, tagihan yang timbul di kemudian hari, jual beli pemilikan aset fisik oleh lembaga keuangan, Efek bersifat investasi yang dijamin oleh pemerintah, sarana peningkatan investasi/arus kas serta aset keuangan setara, yang sesuai dengan Prinsip-prinsip Syariah.

f. Surat berharga komersial Syariah adalah surat pengakuan atas suatu pembiayaan dalam jangka waktu tertentu yang sesuai dengan Prinsip-prinsip syariah. (Hanif, 2012 : 5-6)

\section{Kriteria Efek Syariah}

Dewan Syariah Nasional(DSN) suatu lembaga di bawah MUI (Majelis Ulama Indonesia) yang dibentuk tahun 1999 melalui Fatwa DSN Nomor : 40/DSNMUI/X/2003 Tanggal 4 Oktober 2003 Pasar Modal dan Pedoman Umum Penerapan Prinsip Syariah di bidang Pasar Modal, telah menentukan kriteria produk-produk investasi sesuai ajaran Islam,antara lain :

1. Jenis usaha, produk barang dan jasa diberikan serta capa pengelolaan perusahaan emiten tidak bertentangan dengan prinsipsyariah seperti usaha perjudian atau permaianan yang tergolong judi atau perdagangan yang dilarang.

2. Pelaksanaan transaksi harusdilakukan menurutprinsipkehati-hatian tidakboleh mengandung unsur gharar, riba naisir, risywah,maksiat dan kezaliman. 


\section{E. Perkembangan Pasar Modal Syariah Di Indonesia}

Jika dilihat perkembangan pasar modalsampai tahun 2013 jumlah emiten yang listing di BEI sebanyak 480 perusahaan dengan nilai kapitalisasi sebesar Rp.4.512.714 triliun. Berdasarkan Daftar Efek Syariah (DES) terdapat 309 saham yang sesuai denganprinsip syariah (www.idx.co.id). Banyaknya jumlah saham yang masuk dalam DES menjadikan pilihan bagi investor untuk memilih lebih banyak saham-saham syariah dalam menanamkan modalnya.

Meskipun pertumbuhan pasar modal syariah cukup menggembirakan, namunekspos pasar modal syariah masih minim. Kurangnya pemahaman masyarakat mengenai pasar modal syariah menjadi keraguan bagi investor untuk menanamkan modalnya pada pasar modal. Hal ini dikarenakan adanya praktik kegiatan di pasar modal yang mengandung unsur spekulasi. Oleh karena itu, dibutuhkan pengetahuan mengenai pasar modal syariah, baik dari konsep dan prinsip, serta mekanisme perdagangannya. (Nurlita, $2014: 4$ )

\section{F. Karakteristik Pasar Modal Syariah}

Menurut Mokhtar Muhammad Metwally (Rifai, 2009) karakteristik pasar modal syariah adalah:

1. Semua saham harus diperjual belikan pada bursa efek.

2. Bursa perlu mempersiapkan pasca perdagangan dimana saham dapat diperjualbelikan melalui pialang.

3. Semua perusahaan yang mempunyai saham yang dapat diperjualbelikan di bursa efek diminta menyampaikan informasi tentang perhitungan (account) kentungan dan kerugian serta neraca keuntungan kepada komite manajemen bursa efek, dengan jarak tidak lebih dari tiga bulan sekali.

4. Komite manajemen menerapkan harga saham tertinggi (HST) tiap tiap perusahaan dengan interval tidak lebih dari tiga bulan sekali.

5. Saham tidak boleh diperjual belikan dengan harga lebih tinggi dari HST .

6. Saham dapat dijual dengan harga dibawah HST.

7. Komite manajemen harus memastikan bahwa semua perusahaan yang terlibat dalam bursa efek itu mengikuti standarakuntansi syariah. 
8. Perdagangan saham mestinya hanya berlangsung dalam satu minggu priode perdagangan setelah menentukan HST

9. Perusahaan hanya dapat menerbitkan saham baru dalam periode perdagangan dengan harga HST.(Awaluddim, 2016 : 139-140)

\section{G. Fungsi Pasar Modal Syariah}

Menurut M. Metwally sebagaimana dikemukakan oleh Heri Sudarsono, menyebutkan ada lima fungsi dari pasar modal syariah. Kelima fungsi pasar modal syariah tersebut adalah sebagai berikut (Sudarsono 2007: 186):

a. Memungkinkan bagi masyarakat berpartisipasi dalam kegiatan bisnis dengan memperoleh bagian dari keuntungan dan resikonya.

b. Memungkinkan para pemegang saham menjual sahamnya guna mendapatkan likuiditas.

c. Memungkinkan perusahaan untuk meningkatkan modal dari luar untuk membangun dan mengembangkan lini produksinya.

d. Memisahkan operasi kegiatan bisnis dari fluktuasi jangka pendek pada harga saham yang merupakan ciri umum pasar modal konvensional.

e. Memungkinkan investasi pada ekonomi itu ditentukan oleh kinerja kegiatan bisnis sebagaiman tercermin pada harga saham.

f. Dari beberapa fungsi pasar modal syariah di atas diketahui bahwa keberadaan pasar modal syariah sangat bermanfaat dalam rangka meningkatkan aktifitas perekonomian umat Islam dan selanjutnya dapat meningkatkan kesejahteraan mereka.

Indeks Saham Syariah

1. Jakarta Islamic Index

2. DES (Daftar Efek Syariah) http://blog.valbury.co.id/article/read/Jenis-Jenis-IndeksSaham-BEI-Yang-Perlu-Diketahui, diakses tanggal 16 Oktober 2018)

\section{Perbedaan Pasar Modal Syariah dan Konvensional}

Dari penjelasan berdasarkan teori yang dijelaskan di atas, maka dapat penulis simpulkan beberapa perbedaan pasar modal dan pasar modal syariah. Adapun perbedaan-perbedaan itu antara lain : 
1) Pasar modal syariah efek yang diperdagangkan haruslah dari perusahaan yang dalam menjalankan kegiatan operasional perusahaannya tidak bertentangan dengan prinsip-prinsip syariah. Sedangkan dalam pasar modal biasa tidak ada aturan yang mengatur tentang kegiatan operasional perusahaan.

2) Landasan hukum pasar modal syariah pada dasarnya adalah Al-Qur'an dan Hadis di pertegas dengan Fatwa Dewan Syariah Nasinonal (DSN) sedangkan pasar modal konvensional adalah Undang-Undang Pasar Modal yaitu Undang-Undang No.8 tahun 1995.

3) Dalam pelaksanaan kegiatannya pasar modal syariah diawasi oleh DSN (Dewan Syariah Nasional), sedangkan pasar modal konvensional tidak.

4) Indeks harga saham konvensional anatara lain IHSG, LQ45, Kompas 100 dll, dan Indeks harga saham syariah ialah JII (Jakarta Islamic Index) dan DES (Daftar Efek Syariah )

\section{SIMPULAN}

Dari hasil penelitian ini dapat disimpulkan bahwa:

1) Pasar modal syariah efek yang diperdagangkan haruslah dari perusahaan yang dalam menjalankan kegiatan operasional perusahaannya tidak bertentangan dengan prinsip-prinsip syariah. Sedangkan dalam pasar modal biasa tidak ada aturan yang mengatur tentang kegiatan operasional perusahaan.

2) Landasan hukum pasar modal syariah pada dasarnya adalah Al-Qur'an dan Hadis di pertegas dengan Fatwa Dewan Syariah Nasinonal (DSN) sedangkan pasar modal konvensional adalah Undang-Undang Pasar Modal yaitu Undang-Undang No.8 tahun 1995.

3) Dalam pelaksanaan kegiatannya pasar modal syariah diawasi oleh DSN (Dewan Syariah Nasional), sedangkan pasar modal konvensional tidak.

4) Indeks harga saham konvensional anatara lain IHSG, LQ45, Kompas 100 dll, dan Indeks harga saham syariah ialah JII (Jakarta Islamic Index) dan DES (Daftar Efek Syariah ) 


\section{DAFTAR PUSTAKA}

Awaluddin, 2016. "Pasar Modal Syariah : Analisis Penawaran Efek Syariah di Bursa Efek Indonesia”. Jurnal Kajian Ekonomi Islam, Vol. 1 NO. 2. 2016.

Akhmad Fauzan. 2013. "Konsep Pasar Modal Syariah. Sekolah Tinggi Agama Islam Negeri Purwokerto" afa_ozan@yahoo.com.www. Portal Garuda.ac.id.

Hanif. 2012. "Perkembangan Perdagangan Saham Syariah di Indonesia”.Asas, Vol.4. No.1

Huda, Nurul dan Mohamad Heykal. 2010. Lembaga Keuangan Islam Tinjauan Teoritis dan Praktis, Jakarta: Kencana.

Nurhayati, Sri dan Wasilah. 2015. Akuntansi Syariah Di Indonesia, Salemba Empat : Jakarta

Nurlita, Ana. 2014. "Investasi di PasarModal Syariah dalam Kajian Islam". Jurnal Penelitian Sosial Keagamaan, Vol.17 No. 1, 2014.

Sudarsono, Heri. 2008 . Bank dan Lembaga Keuangan Syariah Deskripsi dan Ilustrasi. Yogyakarta: Ekonisia.

\section{Internet}

http://blog.valbury.co.id/article/read/Jenis-Jenis-Indeks-Saham-BEI-Yang-PerluDiketahui, diakses tanggal 16 Oktober 2018) 
56 | Fadilla Pasar Modal Syariah dan Konvensional 